\title{
DIE BOU VAN DIE STAATSARTILLERIEKASERNE, POTGIETERSTRAAT, PRETORIA: DIE UITBREIDING IN 1924 OM DIE HOOFKWARTIER VAN DIE UNIE. VERDEDIGINGSMAG TE HUISVES
}

\begin{abstract}
Kol Dr Jan Ploeger*
This article describes the coming into existence of the State Artillery Baracks, Potgieter Street, Pretoria and the expansion in 1924 in order to accomodate Defence Headquarters.
\end{abstract} The attention of the reader is invited to an article by the same author, which appeared in Militaria
2 volume 2, on Defence Headquarters.

\section{Inleiding.}

Tydens die bewind van staatspresident T.F. Burgers is in 1875 deur die Transvaalse regering besluit om ' $n$ artilleriekorps, bekend as die 'Batterÿ Dingaan', onder aanvoering van kapt Otto Riedl, op te rig. Die korps het oor 'n kaserne, met 'n magasyn en 'n oefenterrein beskik wat bekend gestaan het as die Kommissariaatplein en geleë was op die hoek van Paleis- en Vermeulenstraat, wes van die Paleis van Justisie.

Met die anneksasie van die Republiek, op 12.4.1877, het die korps verdwyn en het 'n Britse militêre kamp sy verskyning aan die suidekant van die dorp, in die omgewing van Potgieterstraat, ontstaan.

$\mathrm{Na}$ die herstel van die onafhanklikheid van die Zuid-Afrikaansche Republiek, in 1881, is 'n artilleriekorps, bekend as die 'Artilleriekorps van die Zuid-Afrikaansche Republiek', in die lewe geroep.

Hierdie korps, wat in die volgende jare onder verskillende benamings sou bekend staan, was in 'n voormalige Britse militêre kamp, aan Potgieterstraat gehuisves, op dieselfde plek waar tans die Verdedigingshoofkwartier van die Suid-Afrikaanse Weermag gevestig is.

Bestaande geboue is gebruik en van tyd tot tyd het nuwe geboue verrys. Reeds voordat die Jameson-inval plaasgevind het, is planne beraam om die bestaande artilleriekorps te reorganiseer en uit te brei. Die reeds genoemde inval het die uitvoering van hierdie en ander verdedigingsplanne verhaas. In 1896 is besluit om met die bou van 'n nuwe artilleriekaserne te begin. ${ }^{1)}$

\section{Reorganisasie en uitbreiding}

In Wet no 1, 1896, bekend as die 'Wet voor de Staats-Artillerie van die Z-A. Republiek', is o.m. bepaal dat die korps uit die afdelings rydende-, berg- en vestingartillerie sou bestaan en dat die sterkte uit ongeveer 400 offisiere en manskappe sou bestaan, ${ }^{2)}$ Burgers, deur geboorte of naturalisasie, kon as lede van die korps toetree, terwyl diensneming by die afdeling veldtelegrafie tot die eersgenoemde groep beperk was. ${ }^{3}$ )

Die wet is op 5.6.1896 deur staatspresident S.J.P. Kruger en staatsekretaris dr. W.J. Leyds onderteken en vyf dae later het die Uitvoerende Raad besluit om die tender van die 'Italiaansche Boucomaatschappÿ, ten bedrae van $£ 58250$ vir die bou van 'n nuwe artilleriekaserne te aanvaar. Omdat die gange van die toekomstige gebou 10 voet breed moes wees in vergelyking met die aanvanklik bedoelde 6 voet, is ' $n$ bedrag van $£ 2000$ aan die eersgenoemde bedrag toegevoeg. ${ }^{4)}$

Op dié wyse is die bou van die artilleriekaserne aan die Societa Italiana di Costruzioni, ook bekend as die 'Italian Building Company', opgedra. Die maatskappy se kantoor was op die hoek van Markt- en Skinnerstraat, Pretoria, gevestig.

Op 8.7.1896 het die hoof van die Departement Openbare Werke, S. Wierda, die kommandantgeneraal, genl P.J. Joubert, meegedeel dat, die bestaande kampgeboue ontruim en verwyder moet word. Die tender was deur die Uitvoerende Raad goedgekeur, die kontrak was geteken en die kontrakteur kon nou sy aansprake op die terrein laat geld waarop die nuwe kaserne sou verrys. ${ }^{5)}$ 


\section{Die boubedrywighede begin. Tekeninge en spesifikasies.}

Op 21.7.1896 het die boumaatskappy toestemming gevra om tydelike geboue vir werkers naby die bouterrein op te rig en om op die bestaande kampterrein bakstene te vervaardig en 'n tremspoor aan te lê om klip te vervoer. Hierdie klip sou uit die berg gehaal word wat aan die bopunt van Potgieterstraat geleë was. ${ }^{6}$ Wat die tydelike geboue betref, was dit die bedoeling om 'tydelike losieshuis vir Blanke werkers en slaapplekke vir Swart arbeiders op te rig. Op 15.9.1896 is om ' $n$ vergunning gevra om ' $n$ soortgelyke trem verbinding na die steenbakkery tot stand te bring. ${ }^{7)}$

'Terwyl die voorbereidende werksaamhede met betrekking tot die bou van die kaserne aan die gang was, het die Departement van Openbare Werke reeds op 20.2.1896 die spesifikasies, sowel as 'n viertal boutekeninge gereed gehad en is o.m. vermeld:

'dat het hart van het gebouw komt te liggen in de hart lÿn van het daarachter gelegen drilplein (zÿnde het hart van de Scheidingstraat), en met den achtergevel 200 voet uit de verlengde hartlÿn der Parkstraat. ${ }^{18)}$

Die lengte van die voor- en agtergewel van die kaserne is op 315 voet vasgestel, terwyl die lengte van die sygewels op ruim 106 voet vasgestel is. Die twee binnepleine sou 113 by 37 voet word, terwyl die bokant van die toringkoepel ruim 82 voet bo die begane grond sou verrys. Die kaserne sou uit 'n tweetal verdiepings en solder bestaan en die boutyd is op 18 maande bepaal. ${ }^{9)}$

In die loop van die week van 20.7.1896 tot 25.7.1896 is met die bou van 'n tydelike kantoor vir die kontrakteur begin, terwyl die aanleg van 'n treinspoor, om uitgegrawe grond te verwyder en stene van die steenbakkery aan te ry, ruim twee weke later begin is. Daarna is ' $n$ soortgelyke verbinding met die klipgroef tot stand gebring. Op 1.11.1896 is met die uitgrawingswerk van die fondasie begin. Hierdie werk het 'n geruime tyd in beslag geneem wanneer daar in aanmerking geneem word dat op 4.1.1897 begin is om die klipfondasie te messel. ${ }^{10)}$

Verder het J.C. Gerrits in bogenoemde verslae o.m. melding gemaak van die afbreek van 'n bestaande ringmuur op die bouterrein en dat in Augustus opslagplekke vir kalk gebou en 'n masjien met 'n stoomketel opgerig is om die kalkbereiding ter hand te kan neem. In Oktober 1896 is die bestaande kaserne gesloop, in November is 52 vragte klip aangery en in Januarie 1897 is ' $n$ hoeveelheid sandsteen op die terrein afgelewer. In die loop van die derde week van Maart 1897 is 50000 bakstene aangevoer. Hierdie stene is gebruik om die binnemure te messel. Deurkosyne is opgestel en graniet en sandsteen is op die bouterrein afgewerk. In Junie 1897 is begin met die aanvoer van bakstene van Daspoort. Dit is onbekend of die bakstene, wat aanvanklik gebruik is, op of naby die bouterrein vervaardig is, maar die aanleg van 'n treinspoor vir die vervoer van stene dui op die bestaan van so 'n moontlikheid. ${ }^{11)}$ Inmiddels is die voorplein van die kaserne, sowel as die drilplein agter die gebou waar nodig opgevul en gelyk gemaak.

Die messelaars het onder toesig van Italiaanse voormanne gewerk en omstreeks 20.8.1897 was die werksaamhede sover gevorder dat die ysterbalke, tussen die eerste en tweede verdieping gelê kon word. Omstreeks 20.11.1897 is begin met die opstel van die dakhout, terwyl daarna begin is om die messelwerk van die hoekpaviljoene op die vereiste hoogte te bring. In die week van 14.3.1898 tot 19.3.1898 is begin om asfaltvloere in die slaapsale op die eerste verdieping en in die ruskamers te lê. Aan die begin van Mei 1898 was hierdie werk voltooi, terwyl in die tweede helfte van die daaropvolgende maand bome op die voorplein geplant is. Omstreeks dieselfde tyd is die kaserne, wat nog nie heeltemal gereed was nie, in gebruik geneem. Die eintlike oordrag van die gebou het in die loop van die week van 12.9 .1898 tot 17.9 .1898 plaasgevind.

\section{Die oordrag van die kaserne}

Die oordrag van die kaserne aan die regering het, volgens 'n nog bestaande sertifikaat, op 14.9.1898 plaasgevind. Aangesien dit, volgens die kontrak, op 8.7.1898 moes geskied het, is ' $n$ boete van $£ 10$ per dag van die tenderprys afgetrek, terwyl ' $n$ bedrag van $£ 400$ teruggehou is omdat die kontrakteur die toring se uurwerk nie gelewer het nie. ${ }^{14)}$

Op 25.3.1899 is die laaste gedeelte van die bousom aan die kontrakteur betaal nadat die onderhoudstydperk verstryk het. ${ }^{15)}$ Hierdie betaling het 'n bedrag van $£ 2360$, m.a.w. $4 \%$ van die tenderprys van $£ 59000$, verteenwoordig.

Die vertragings, wat veroorsaak het dat die ka- 
serne. na die verstryking van die boutyd van 18 maande nog nie voltooi was nie, is o.m. aan die trae aflewering van bakstene en die aanleg van die voor- en die drilplein toegeskryf.

\section{Twee kontraktante}

Soos reeds vermeld is, is die oorspronlike kontrak in verband met die bou van die kaserne met 'n Italiaanse maatskappy aangegaan. Op 10.2.1897 het die hoof van die Departement van Openbare Werke 'n skrywe van die Franco Italian Building Co., Pretoria, ontvang waarin verklaar is dat dié maatskappy die kontrakte van sy voorganger oorgeneem het. Redes vir dié optrede is nie verstrek nie, maar wel is vermeld dat die direkteur van die Banque Francaise de l'Afrique du Sud dié transaksie goedkeur en die aangegane verpligtings ook ten opsigte van die nuwe kontrakteur sou nakom. Wierda het geantwoord dat daar, van sy kant, geen beswaar teen die oordrag bestaan nie. ${ }^{16)}$

Die oordrag verklaar ook dat op 2.2.1897 die eerste een-twintigste deel van die tenderbedrag, nl. £2 950, aan die nuwe kontrakteur uitbetaal is en nie aan sy voorganger nie.

\section{Die kommandant-generaal se verslae (1896 1898)}

In sy jaarverslag oor 1896 het die kommandantgeneraal nadruk gelê op die huisvestingsvraagstukke waarmee die artilleriste in dié jaar te kampe gehad het. As gevolg van die uitbreiding van die korps moes 'n noodkaserne en -stalle gebou word. In dié tydelike kaserne het die Rydende Artillerie sy intrek geneem. Die Bergartillerie het die ou kaserne en die ou stalle in gebruik geneem.

In sy verslag oor 1898 kon die kommandantgeneraal met trots vermeld.

'De nieuwe kazerne werd, na door de aannemers afgelewerd te sÿn, in gebruik genomen. Ook werd de electrische verlichting in dienst gesteld.

De Zuid-Afrikaansche Republiek is nu in bezit van een kamp, zooals bÿna nergens ter wêreld bestaan ... '18)

\section{6. 'n Nuwe bestemming}

Die Britse militêre besetting van Pretoria, aan die begin van Junie 1900 was die begin van 'n nuwe hoofstuk in die geskiedenis en bestemming van die nou voormalige kaserne van die Staatsartillerie. Die gebou het na 1902 die setel van die Britse militêre hoofkwartier in Suid-Afrika geword.

$\mathrm{Na}$ die totstandkoming van die Unie in 1910 en die Verdedigingswet 1913 en die Unie Verdedigingsmag in dieselfde jaar, is - aan die begin van Oktober 1914 die offisierswoning aan Artillery Row deur offisiere van die South African Mounted Rifles (Zuid-Afrikaansche Bereden Schutters betrek. Die hoekhuis, no 1, bekend as die 'Commandants House' is deur It kol Dawson betrek. Behalwe dat die genoemde huise aan offisiere van die SAMR/ZA BS toegewys is, het 'n tweetal dienswonings - wat aan Magasynweg geleë was, ook nuwe bewoners gekry. ${ }^{19}$

Reeds voordat hierdie veranderings plaasgevind het, is op 29.9.1914 sekere geboue op die kaserneterrein deur die Departement van Openbare Werke oorgeneem. Een van hierdie geboue was die hoofkwartierblok. Hierdie oorname kan gedeeltelik toegeskryf word aan die verskuiwing van die Militêre Skool van Tempe (Bloemfontein) na Pretoria, maar van deurslaggewende belang was die feit dat die Britse militêre hoofkwartier in Suid-Afrika met ingang van 1.9.1914 na Kaapstad oorgeplaas is. ${ }^{20)}$

Reeds op 28.8.1914 het die Britse militêre opperbevelhebber in Suid-Afrika, It-genl J. Wolf-Murray in verband met dié aangeleentheid aan die Unie se Minister van Verdediging (genl J.C. Smuts) geskryf:

'The Headquarter Block Artillery Barracks, at present used as Head Quarters, South African Command, can be handed over to the Union Department at a date, to be subsequently arranged, after my Headquarters move to Cape Town on 31st August.

The conditions of this transfer will, of course be governed by whatever decision may be arrived at in connection with the general question of Colonial Military Lands in South Africa... ${ }^{121)}$

Op 11.9.1914 is, in die vorm van 'n afskrif, die sekretaris van die Departement van Openbare Werke, soos volg deur die Sekretaris van Verdediging oor verdere verwikkelings in bogenoemde verband ingelig:

'The Offices of the Executive Commanders Union Defence Force, the District Staff Officer No. 9 Military District, the Active Citizen 
Units, whose headquarters are at Pretoria, will shortly be established at the Headquarters Block, Artillery Barracks. In the case of the latter they move in tomorrow. 22$)$

Terwyl die hoofgebou op die terrein aan Potgieterstraat deur bogenoemde militêre instansies in gebruik geneem is, is van die ander geboue in September 1914, tydens die mobilisasie van die SAMR/ZABS benut.

In sy reeds genoemde bydrae oor die hoofstedelike militêre geskiedenis het F.J. du Toit Spies vermeld dat, voor die verskuiwing van die opperbevel e.d.m. van die Unieverdedigingsmag na Potgieterstraat in 1914 brig-genl C.F. Beyers (Aktiewe Burgermag) en sy staf in die destydse N.Z.A.S.M. huis in Marktstraat (vandag: Paul Krugerstraat) gehuisves was, terwyl die hoofkwartier van kol. P.S. Beves (Kadette) in 'n gebou gevestig was op die huidige Pretoriusplein. Die hoofkwartier van brig-genl H.T. Lukin (SAMR/ZABS; Staande Mag) was, volgens dieselfde skrywer, in die voormalige Artilleriekaserne, Potgieterstraat, gehuisves. ${ }^{23)}$

'n Sekere mate van ko-ordinasie en sentralisasie van die UVM is weliswaar in 1914 deur die verskuiwing na Potgieterstraat verwesenlik, maar daarmee was die hele proses nog nie afgerond nie.

In 1919 het 'n seker W.J. Woolley 'n verslag opgestel waarin hy, die huisvesting van die Generale Staf van die UVM in oënskou geneem het. Die deel van die UVM-organisasie sowel as die Sekretaris van Verdediging was op die tydstip in 'n huis en 'n aantal hutte aan Marktstraat gehuisves. Woolley het, in sy verslag van 23.7.1919, behoorlike huisvesting vir die Generale Staf bepleit en o.m. verklaar.

'If a higgledy-piggledy lot of rooms in cottages are used for staff work you cannot have economy or efficiency. ${ }^{24)}$

Op 12.9.1919 het die Distrikingenieur van Openbare Werke op dieselfde aangeleentheid teruggekom en die bou van 'n nuwe vleuel by die bestaande gebou in Marktstraat voorgestel.

Op 7.12.1921 het die Staatsdienskommissie, in 'n verslag aan die Sekretaris van Openbare Werke, o.m. die volgende onder laasgenoemde se aandag gebring:

'The Secretary and Chief Military Officers of the Defence Department with their respective staffs are accommodated in somewhat rambling offices in Market Street.

There can be no question that increased efficiency and economy in administration would result by the transfer of Defence Headquarters to the Artillery Barracks.

The ground floor of the latter is at present occupied by offices which might well be moved elsewhere but even with the relief thus afforded it is impossible for us to say whether the move of Defence Headquarters could be effected without adding another storey to the building. ${ }^{.25)}$

In 1922 is oorweeg om die bestaande binnepleine van die voormalige Artilleriekaserne, Potgieterstraat, in kantore te verander, maar hierdie plan, sowel as dié wat die bou van 'n derde verdieping op die bestaande vroeëre kaserne beoog het, het nie die goedkeuring van die betrokke gesagdraers weggedra nie. ${ }^{26)}$

\section{7. 'n Nuwe gebou voor die voormalige kaserne}

Op 11.7.1924 het argitek J.S. Clelland aan die Sekretaris van die Departement van Openbare Werke meegedeel dat die oprigting van 'n nuwe gebou, van drie verdiepings, voor die vroeëre kaserne, en wysigings in die vroeëre kaserne ' $n$ koste van ruim $£ 56000$ sou verg.

Die vloeroppervlaktes, wat op die tydstip in gebruik was, was soos volg ingedeel: Die voormalige kaserne, sonder die solder: 25168 vierkant voet; die hoofkwartier (Markstraat): 26700 vierkant voet; die Mediese Diens (Uniegebou); 2820 vierkant voet. Totaal: 54688 vierkant voet. Deur die nuwe gebou op te rig sou, saam met die beskikbare vloeroppervlakte in die destydse kaserne, in totaal 62944 vierkant voet vloeroppervlakte beskikbaar kom. ${ }^{27)}$

Op 14.8.1924 het brig-genl A.J. Brink die betrokke minister se goedkeuring vir die bou van die nuwe gedeelte, met insluiting van die verskuiwing van die Mediese Diens, goedgekeur en verder vermeld:

'Accommodation for the Minister and Staff, myself and the General Staff Section should be provided in the front of the new building on the storey above the ground floor - that is, the middle storey. ${ }^{28)}$ 
Veranderings aan die vroeëre kaserne sou deur die SA Genie uitgevoer word.

Die skrywer het die geskiedenis van die oprigting van die nuwe, voorste gedeelte van die huidige Verdedigingshoofkwartier nie nagevors nie, maar homself beperk tot die studie tot die tot- standkoming van die sentrale gedeelte van die geboue op ' $n$ terrein wat gedurende meer as ' $n$ eeu ten nouste verbind is met die verskillende elemente waarop ons hedendaagse militêre tradisie berus.

${ }^{*}$ Kol dr Jan Ploeger, is Staatshistorikus verbonde aan die Staatsargief, Pretoria

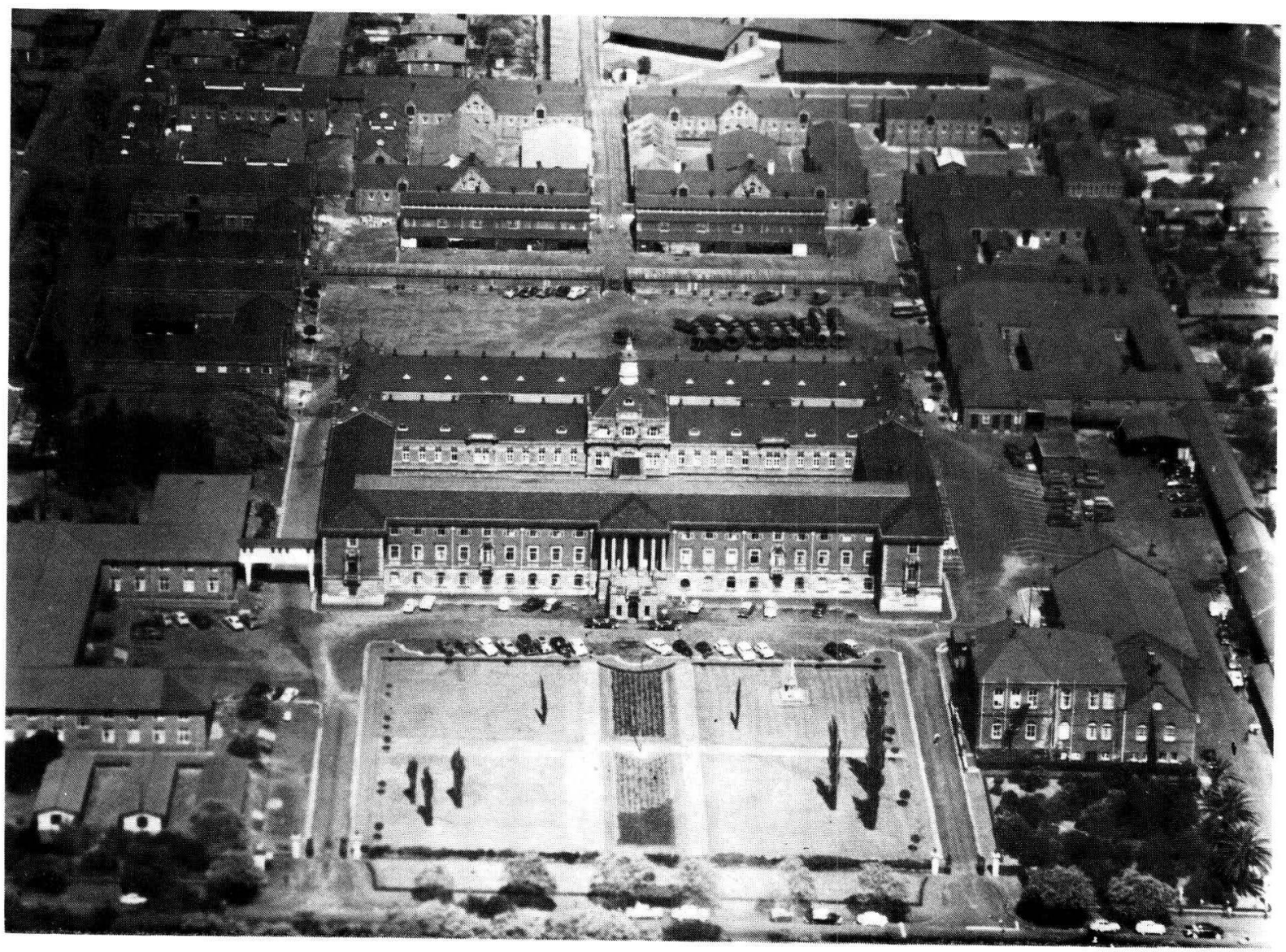

\section{Aantekeninge}

VHK en omringende geboue

1. Pretoria 1855 - 1955 (Pretoria, 1955), F.J. du Toit Spies, 'Bladsye uit die Militêre Geskiedenis van Pretoria, pp. 90 - 98.

2. Locale Wetten der Z.-A. Republiek. 1896; Wet no. 1, 1896, art. 4 - 8 .

3. Hid., p. 7, art. 12.

4. TAB, URB, art. 489, 10.6.1896. In band UR 13.

5. Hid., KG 74/2, CR 5036/96 by CR 4750/96, Hoof Publieke Werke Kommandant-generaal, 8.7.1896.

6. Ibid., KG 74/2, CR 5282/96, Societa di Costruzione - Kommandantgeneraal, 21.7.1896.

7. Ibid., KG 6252/96, 15.9 .1896 (register).

8. Ibid., PW 168, Bestek no. 299 (met 4 tekeninge), p. 1.

9. Ibid., pp. 2, 3, 22.

10. Ibid., PW 146, Weeklikse verslae 20.7.1896 - 9.1.1897.

11. Ibid., Weeklikse verslae tot 26.6.1897.

12. Ibid., Verslag 2.8.1897.

13. Ibid., Verslag 12.9.1898 - 17.9.1898.

14. Ibid., R7142/96, Sertifikaat, 14.9.1898.

15. Ibid., Sertifikaat, 25.3.1899.

16. Ibid., PW 350 (briewekopieboek), p. 124, Hoof van Openbare Werke. Direkteur 'The Franco Italian Building Co' 1.3.1897. Die plaaslike bestuurder (direkteur was 'n sekere C. Simon.

17. $\mathrm{KG}$ - verslag oor $1896, \mathrm{p} .7$

18. Ibid., oor 1898 , p. 11.

19. Sentrale Argiefbewaarplek, Pretoria, PW2/12344, P2/78, District Engineer Public Works Department - Secretary Public Works Department, 7.10.1914. Die laasgenoemde offisierswonings is vermoedelik, in 1915 oorgeneem.
20. Ibid., P2/73, District Engineer Public Works Department - Secretary Public Works Department, 10.10.1914.

21. Ibid., CRSA 15630/241 (DBO), Lieut.-Gen. J. Wolfe Murray - Minister of Defence, 28.8.1914. Die Britse opperbevelhebber verwys in dieselfde skrywe, na vroeëre korrespondensie oor die aangeleentheid, t.w. sy skrywe CRSA no. 9519/3(CE), van 23.4.1913, met die goewerneurgeneraal (no. 1/555, van 30.4.1913). Hierdie korrespondensie is nie nagegaan nie. Kyk ook PW 12344, Acting Secretary of Defence Secretary Public Works Department, 12.8.1914, in verband met die toekomstige oorname van die huidige VHK-kompleks en die destydse Roberts Heights.

22. Ibid., Secretary of Defence - Secretary Public Works Department, 11.9.1914. Kyk ook PW2/12344, Assistent Secretary Public Works Department - Secretary Public Works Department, 28.2.1923.

23. Pretoria 1855 - 1955, p. 108.

24. PW 14357, deel 1, Extract from Report by Mr. W.J. Woolley, 23.7.1919.

25. PW 12344, IF 6950/CC/1, Secretary Civil Service Commission - Secretary Public Works Department, 7.12.1921.

26. Ibid., 24.1.1922. Verwys na tekening no. 4831/A.

27. PW 14357, J.S. Clelland - Secretary Public Works Department, 11.7.1924.

.28 Ibid., Brig.-genl. A.J. Brink - KMG, 14.8.1924. Volgens 'n skrywe van die Sekretaris van Openbare Werke aan HGS, 29.8.1924, in dieselfde lêer, sou die koste vir veranderings aan die bestaande gebou (skilder- en pleisterwerk, afskortings, nuwe deure, verplasing van bestaande deure e.d.m.) $£ 6500$ bedra. 